\title{
EESTI KOOLILAPS SÕNARAAMATU KASUTAJANA
}

\section{Ruth Mägi}

Ülevaade. Artiklis antakse ülevaade Eesti koolilaste seas 2004/ 2005. õppeaastal läbiviidud uuringust, mille eesmärk oli välja selgitada õpilasest sõnaraamatukasutaja harjumused ja kogemused, kasutamisprobleemid, samuti rahulolu oma oskustega. Uuringu käigus küsitleti ühtekokku 369 koolilast 4.-12. klassist. Mujal maailmas on sõnaraamatute kasutamist uuritud ligikaudu 50 aastat, 1980. aastatest alates võib kõnelda lausa omaette uurimissuunast. Eestis pole sedalaadi uuringuid seni tehtud, siinne kirjutis on seega esimene katse kirjeldada eesti sõnaraamatute kasutamist.

Küsitluse tulemused näitasid, et eestlaste kodudes domineerib kakskeelne inglise-eesti sõnaraamat, mitte ÕS, nagu ehk üldiselt võiks arvata. Koolides seevastu kasutatakse ÕS-i rohkem kui kakskeelset inglise-eesti sõnaraamatut. Kõige rohkem kasutatakse Eesti koolides aga õpikute taga olevaid sõnastikke. Küsitlus näitas, et lapsed ei saa sageli aru, mida sõnaraamat neile öelda tahab - sõnaraamat on suhteliselt keeruline ja tülikas abivahend. Samas on koolilastel head sõnaraamatu kasutamise kogemused ja oma oskustega on nad suuresti rahul.

Võtmesõnad: leksikograafia, pedagoogiline leksikograafia, sõnaraamatu kasutamine, metaleksikograafia, keeleõppija, eesti keel

\section{Sissejuhatus}

Kas üks sõnaraamat on hea või mitte, selle üle saab otsustada üksnes kasutaja. Sageli võib kohata seisukohta, et sõnaraamat on halb, sest seal ei ole seda, mida otsitakse, või et sealt ei leia midagi üles. Sõnaraamatu tulemuslik kasutamine eeldab aga mõndagi nii sõnaraamatult kui ka kasutajalt. Õige sõnaraamatu - kui selline on olemas ja kättesaadav - valimine eeldab, et kasutaja (või tema juhenda- 
ja, vanem, õpetaja) teab, mis talle kõige paremini sobib. Selleks aga peab tal olema mõnevõrra sõnaraamatu kasutamise kogemusi. Tihti juhtub, et õiget sõnaraamatut ei tunta ära.

Artikkel põhineb Eesti koolilaste seas 2004/2005. õppeaastal läbiviidud uuringul, mis käsitleb koolilapsest sõnaraamatukasutaja harjumusi ja kogemusi, probleeme ning rahulolu oma oskustega. Eesti koolilast kui sõnaraamatu kasutajat pole teadaolevalt seni uuritud, samas on mujal maailmas sõnaraamatute kasutamise uurimist alustatud juba 50 aastat tagasi. Siinne kirjutis on seega esimene katse kirjeldada eesti sõnaraamatute kasutamist. Esimeses osas antakse ülevaade sellest, kuidas on sõnaraamatute kasutust maailmas uuritud ja tutvustatakse peamisi meetodeid. Teises osas kõneldakse lühidalt küsimustikust kasutusuuringute abivahendina, lahatakse selle häid ja halbu külgi. Kolmandas osas antakse ülevaade Eestis läbiviidud küsitluse tulemustest.

\section{Kuidas sõnaraamatu kasutamist uuritakse}

Sõnaraamatute kasutusuuringutega alustati maailmas 1960-ndatel, esimese sellelaadse töö avaldas Ameerika leksikograaf Clarence Barnhart (1962), kes uuris ükskeelse sõnaraamatu kasutust Ameerika kolledži tudengite ja õppejõudude seas. Suurem hoog anti uuringutele 1980-ndatel, mil oma tööd avaldasid Henri Béjoint (1981), Reinhard Hartmann (1982) jt. 1990-ndatel ilmus mitu olulist uurimust Sue Atkinsi ja Krista Varantola $(1997,1998)$, Reinhard Hartmanni (1999) jt sulest.

Paul Bogaardsi (2003) järgi on sõnaraamatu kasutusuuringutes seni domineerinud neli meetodit:

- ülevaated;

- metaleksikograafilised uuringud;

- kasutamise modelleerimine;

- eksperimentaalsed uuringud.

Järgnevalt tutvustatakse P. Bogaardsi käsitlusele toetudes neid meetodeid pisut lähemalt.

\section{1. Ülevaated}

Ülevaatlik suund valitses 1980-ndatel. Uuritavatele jagati küsimustikke, kus küsiti, milliseid sõnaraamatuid nad kasutavad, mida sealt otsivad ja kui rahul nad tulemustega on. Üldistamist raskendasid küsimustike metodoloogilised möödalaskmised: mõnel juhul oli tegu heterogeense või piiratud uuritavate rühmaga, teisel juhul olid küsimused ähmased või jäädi tulemuste analüüsil pinnapealseks. Sellegipoolest sai kogutud andmete põhjal väita, et sõnaraamatuid kasutatakse pigem lugemise juures (enamasti selleks, et tundmatu sõna tähendust järele vaadata) kui kirjutamise juures (et sõna õigekirja kontrollida). Viimasest veel vähem läheb sõnaraamatut vaja suuliste ülesannete lahendamisel, st kuulamise või rääkimise puhul. Võõrkeelte õppimisel kasutatakse pigem kakskeelseid kui 
ükskeelseid sõnaraamatuid. Kasutajate rahulolu kõikus väga suurel määral, ulatudes olukorrast, kus rahul olid üksnes pooled kasutajad (55\%), kuni peaaegu täieliku rahuloluni (95\%).

Eesti kooliõpilaste seas läbiviidud uurimus on samuti ülevaatlikku tüüpi.

\subsection{Metaleksikograafiline suund}

Metaleksikograafia on valdkond, mis tegeleb olemasolevate sõnaraamatute kriitikaga, lähtudes konkreetse kasutajarühma oskustest ja keelevajadustest. Kriitilise pilguga uuritakse kõike, mis sõnaartiklis leidub: grammatilist infot, illustratsioone ja näiteid, kasutatud defineerimissõnavara ja -stiili. Selle uurimissuuna juures on kõige rohkem pööratud tähelepanu sellele, kas võõrkeele õppijale sobib paremini ükskeelne või kakskeelne sõnaraamat, samuti on omavahel võrreldud elektroonilisi ja pabersõnaraamatuid. Kõige vähem on metaleksikograafias uuritud emakeelset sõnaraamatukasutajat.

Mis puudutab spetsiaalseid õppesõnaraamatuid, siis pole jõutud märkimisväärsete tulemusteni, mis kinnitaksid nende olulisust võõrkeeleõppes. P. Bogaards arvab, et õigus võib olla teisel selle ala spetsialistil Philip Scholfieldil, kes märgib, et meil on küll sõnaraamatud õppuri jaoks, ent mitte õppimiseks (Scholfield 1999: 299, viidatud Bogaards 2003: 28 järgi).

\subsection{Kasutamise modelleerimine}

Kasutust modelleeriv suund püüab välja selgitada sõnaraamatu kasutamise etapid, et sealt siis uuringuid jätkata. Sõnaraamatu kasutamise protsess algab keeleprobleemi sõnastamisega, mille järel otsustatakse, kas selle probleemi lahendamiseks on vaja avada sõnaraamat või mitte. Selles etapis tuleb esimene takistus: kasutaja ei tea, milline sõnaraamat sobib probleemi lahendamiseks kõige paremini. Kes on sõnaraamatu juba avanud, peab sõnaraamatust leidma sõna, mis probleeme valmistab. Seejärel tuleb leida sellele kanooniline vorm, s.o üldtunnustatud sõnavorm, milles esitatakse sõnaraamatus märksõna. Kanoonilise vormi leidmine eeldab morfoloogilisi teadmisi ja võib olla võõrkeele õppijale keeruline, näiteks peab teadma, et eesti sõnaraamatutes on verbid esitatud $m a$-infinitiivis, soome sõnaraamatutes $d a$-infinitiivis. Kanoonilise vormi abil saab valida märksõna. Kirjeldatud järgus põrkab kasutaja kokku konkreetse sõnaraamatu infoesitusega. Kasutaja leiab suhteliselt hõlpsalt kätte üksi esitatud märksõna, kui aga sõna kuulub sõnaühendisse või on osa väljendist, läheb see etapp tunduvalt keerulisemaks: nüüd oleks hea, ja sageli hädavajalik, kui kasutaja oleks tuttav sõnaraamatu makrostruktuuriga, st sõnaartiklite üldise paigutusega selles sõnaraamatus. Leidnud märksõna, peab kasutaja kindlaks tegema õige alamärksõna või tähenduse, mida vaja läheb, leidma sealt õige info ning kõige paremini sobiva vaste otsitava sõna konteksti arvestades.

Kõige olulisemaks ja ka kõige raskemaks peab P. Bogaards õige ja sobivaima info leidmist sõnaraamatust. Viimane etapp kasutamise modelleerimise juures hõlmabki sõnaraamatu kasutamise tulemuslikkust. Tulemuslikkust võib vaadel- 
da kas kasutaja või eksperdi vaatevinklist. Võib juhtuda, et kasutaja meelest on leitud info sobiv ja õige, kuid eksperdi (täiskasvanud emakeelekõneleja, võõrkeeleõpetaja või leksikograafi) meelest mitte (Bogaards 2003: 30-31).

\subsection{Eksperimentaalne suund}

Eksperimentaalsetes uuringutes on pööratud tähelepanu küsimusele, kas üldse kasutada sõnaraamatut või mitte. Siinkohal on täheldatud, et vastav käitumine oleneb lugemisülesandest ja individuaalsetest erinevustest, samuti oleneb see otsitavate sõnade tüübist. Väga vähe on uuritud seda, kuidas kasutaja otsustab, millist sõnaraamatut avada. Mingil määral on sellele küsimusele vastust otsitud ükskeelse, kakskeelse ja nende vahetüübi, nn kakskeelse seletava sõnaraamatu ${ }^{1}$ omavahelisel võrdlemisel ning nende võrdleval kasutamisel võõrkeeleõppurite seas.

Veel on uuritud olulise info valimist ja siin on jõutud järeldusele, et tähenduse seletused võiksid üldiselt olla lihtsamad ja paremini mõistetavad, seda eriti lastele ja võõrkeeleõppuritele mõeldud sõnaraamatutes.

Uuritud on ka pikkadest sõnaartiklitest teatava infoosa leidmise strateegiaid ning sõnaraamatu kasutamise tulemuslikkust teksti mõistmisel. Kahjuks näitavad mitmed tulemused, et sõnaraamatud ei abista kuigivõrd teksti mõistmist ning nende kasutamine võib vahel isegi kasu asemel kahju teha (Bogaards 1999: 32-33). Mõnevõrra positiivsemate tulemusteni jõudsid Don McCreary ja Fredric Dolezal (1999: 133), kes leidsid, et kui sõnaraamatu kasutamist toetavad kontekstivihjed nii sõnaraamatus ja tekstis (näidete või täpsustuste näol), siis õnnestub teksti mõistmine kõige paremini.

Kokkuvõttes peab Bogaards sõnaraamatute kasutusuuringute suurimaks puuduseks ühtse ja üldiselt heakskiidetud sõnaraamatukasutusteooria puudumist, kuigi 1990-ndate lõpuks ilmus mitu kokkuvõtet mahukatest uuringutest (Tono 1998, Wiegand 1998jt), mis võimaldavad teha olulisi üldistusi (Bogaards 1999: 33).

\section{Küsimustik kasutusuuringu abivahendina}

Sõnaraamatute kasutusuuringud on metodoloogiliselt mitmekesised. Andmete kogumiseks kasutatakse kriitilist ülevaadet, küsimustikku, intervjuud, (eneseanalüüsi) protokolli, eksperimenti ja testi. Küsimustikud on kõige levinum (ja ilmselt kõige lihtsam) vahend andmete kogumiseks. Küsimustike abil saab uurida suhteliselt laia kasutajaskonda, küsimustiku tulemuste najal saab suure mahu korral teha olulisi üldistusi. Küsimustikke kui kasutusuuringute abivahendit on ka kõvasti kritiseeritud. Kõige enam on tsiteeritud Glynn Hatheralli lauset:

Kas uuritavad ütlevad, mida nad teevad, või ütlevad, mida nad mõtlevad, et teevad, või ütlevad, mida nad peaksid tegema, või kõik kolm kokku? (Hatherall 1984: 184, viidatud Lew 2002: 267 järgi)

Alternatiiviks pakub G. Hatherall otsest vaatlust või eneseanalüüsi protokolli kui ainust usaldusväärset võimalust kasutaja käitumise uurimiseks, samas tõdeb ta paradoksaalsel kombel, et uuritavates tingimustes on uurimisalustel raske nor-

${ }^{1}$ See on nn kakskeelestatud tüüp, kus ühes keeles esitatud seletusi täiendab teiskeelne tõlkevaste. Eestis ilmunud sõnaraamatutest kuulub siia tüüpi: Inglise-eesti sõnaraamat. English dictionary for speakers of Estonian. Password. TEA, 1995 
maalselt käituda (Hatherall 1984: 184, viidatud Lew 2002: 267 järgi). Henri Béjoint on väitnud, et küsimustike vastu räägib kaks argumenti: esiteks ei saa kindel olla, kas uuritav on küsimusest aru saanud ning millist vastust oodatakse, teiseks ei või teada, kas tulemused kajastavad uuritavate arvamust sellest, mida nad tegelikult kasutaksid (Béjoint 2000: 147). Mitte ainult küsitluste, vaid muudegi kasutusuuringute suurim probleem ongi selles, kuidas uurida sõnaraamatu kasutamist võimalikult loomulikes tingimustes. Samas on kasutaja jaoks sõnaraamatu järele haaramine niikuinii mingi kõrvalekalle loomulikust lugemis/ kirjutamis/rääkimiskeskkonnast, mistõttu ei tohiks kunstlikult loodud situatsioon olla väga suureks takistuseks andmete töötlemisel.

Robert Lew näeb üht võimalikku lahendust selles, et küsimustike metoodikat ja sisu parandada ning küsimustike kõrval andmete kogumiseks ka mingit muud võimalust kindlasti kasutada (Lew 2002: 268).

Oma küsimustiku eeskujuks olen osaliselt võtnud (eelkõige üldiste küsimuste osas) R. Hartmanni koostatud küsimustiku (vt Hartmann 1999), mida ta kasutas Exeteri ülikooli tudengite seas.

\section{Eesti koolilaste küsitlus}

Ülevaate saamiseks Eesti koolilapsest kui sõnaraamatu kasutajast koostasin 20 küsimusest koosneva küsimustiku (vt lisa 1). Küsimustik on üks osa laiemast uurimusest, mis hõlmab sõnaraamatu kasutaja oskuste ja vajaduste analüüsi Eesti koolilaste seas. Andmete kogumisel kasutasin kaht meetodit. Esmalt küsitlesin õpilasi nende tausta kohta ja palusin neil hinnata ennast kui sõnaraamatu kasutajat. Teiseks kasutasin eksperimentaalse suuna meetodit: et selgitada koolilapse sõnaraamatu kasutusoskust, andsin neile lahendada sõnaraamatuga erinevaid ülesandeid. (See artikkel eksperimenti ei hõlma.)

Küsimustikule vastas ühtekokku 369 last nelja kooli (Tallinna Jakob Westholmi Gümnaasium, Kohtla-Järve Ühisgümnaasium, Tallinna Prantsuse Lütseum, Tallinna Õismäe Humanitaargümnaasium) 4.-12. klassist. Küsimustik oli anonüümne ning sellele vastati emakeele tundides.

Enamik küsimusi oli valikvastustega, vastajatel paluti märkida tema puhul õiged vastused (ka enam kui üks). Tulemusi analüüsisin küsimuste kaupa, st ühtki küsimustikku ei jäetud sellepärast kõrvale, et mõni küsimus oli ebaloogiliselt vastatud või hoopis vastamata jäetud. Selliseid juhtumeid oli kümmekond. Näiteks kui laps jättis eespool vastamata küsimusele, kas tal on kodus sõnaraamatuid, aga hiljem oli siiski loetlenud sõnaraamatuid, mis tal kodus olemas on, siis viimast vastust siiski arvestasin.

Vastajad jagasin vanuse järgi kolme rühma, küsimustiku tulemusi analüüsin nii nende rühmade vahel kui ka sees:

1) põhikooli algaste (4.-6. klass, 79 last, $21 \%$ vastanutest),

2) põhikooli keskaste (7.-9. klass, 121 last, $33 \%$ vastanutest),

3) gümnaasiumiaste (10.-12. klass, 169 last, $46 \%$ vastanutest).

Küsimused olid jagatud nelja rühma: 1) vastajast üldiselt, 2) vastaja sõnaraamatutest üldiselt, 3) vastaja sõnaraamatute kasutamisest ja 4) sõnaraamatu kasutaja rahuolust. Järgnevalt vaatlen küsimustiku tulemusi nende nelja jaotise kaupa. 


\subsection{Vastajatest}

Küsimused vastaja kohta andsid infot selle kohta, mis soost on vastaja, mitmendas klassis ta käib, mis keeli kodus räägitakse ja mis võõrkeeli ta koolis õpib.

Vastaja sugu. 369 vastanust oli $38,5 \%$ poisid, $60,7 \%$ tüdrukud ja $0,8 \%$ jätsid oma soo mainimata. Rühmadevahelised sooerinevused on minimaalsed. Kõige rohkem poisse on põhikooli algastmes (39,2\%), kõige vähem keskastmes $(37,2 \%)$.

Kodus räägitavad keeled. Enamiku laste kodudes räägitakse eesti keelt, vastuseid, kus nimetati, et ainult eesti keelt, oli 85\%. Kõige enam kõneldakse eesti keelt gümnaasiumiõpilaste kodudes (91,1\%). Küsimust võis vastaja mitmeti tõlgendada - mis keeles kodus suheldakse, mis keeli lapsevanemad räägivad, mis on vastaja või vanema emakeel. (Siin oligi kohe tegemist H. Béjointi osundatud raskusega (vt eespool): kuidas tagada, et küsimusest ühtmoodi, n-ö õigesti aru saadakse.) Mitmel juhul oli eesti keele kõrval teiseks kodus räägitavaks keeleks vene keel (7,6\%) või inglise keel (6,1\%), vähem soome keel (o,8\%). Kõige rohkem mainisid mitut keelt keskastme lapsed $(5,1 \%)$, selles astmes oli ka kõige enam eesti ja vene keele nimetajaid. Paar last nimetas ka prantsuse ja saksa keelt, üks laps gruusia keelt.

Õpitavad võõrkeeled. Vastajal oli võimalik valida inglise, saksa, prantsuse, vene ja mõne muu keele vahel, viimasel puhul paluti keel nimetada. Vastajad valisid kas ühe keele või mitu keelt, olenevalt sellest, millise kooliastmega on tegu. Ootuspäraselt õpivad kõik inglise keelt, teisena mainiti vene keelt, kolmandana prantsuse keelt, seejärel saksa keelt.

Joonis 1 illustreerib võõrkeelte õppimist. Kõige rohkem (28,5\% vastanutest) õpitakse ühtaegu inglise, prantsuse ja vene keelt (kõigis rühmades, kõige enam keskastme laste seas); pisut vähem (23,3\%) lapsi õpib inglise ja vene keelt (kõige rohkem keskastme lapsed, kõige vähem gümnaasiumis); 15,2\% õpib inglise, vene ja muud (hispaania või ladina) keelt (gümnaasiumiastmes); 11,7\% inglise, saksa, vene keelt (peamiselt gümnaasiumi õpilased); 7,9\% ainult inglise keelt (suurem osa põhikooli algastme lapsi). Kõige suuremad keeleõppijad on vanima kooliastme lapsed, mis on ka loomulik, vanemas astmes on võimalik valida endale juba vabaaineteks erinevaid võõrkeeli.

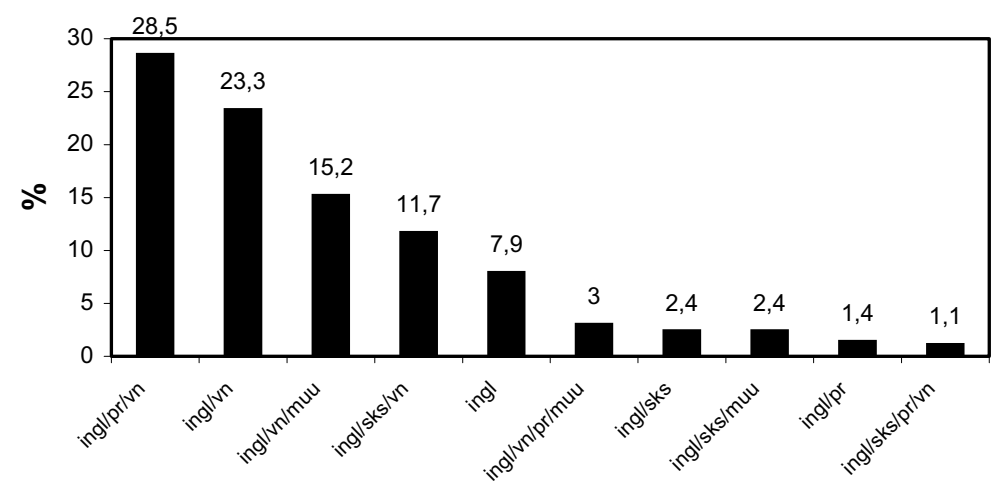

Joonis 1. Õpitavate võõrkeelte jaotus vastanute vahel 


\subsection{Olemasolevatest sõnaraamatutest}

Selles küsimusteplokis tuli vastajal vastata, kas ja milliseid sõnaraamatuid tal kodus ja koolis leidub.

Sõnaraamatud kodus ja koolis. Üldiselt on kõigil (99,5\%) lastel kodus mingid sõnaraamatud olemas. Vaid kaks last arvasid, et nende kodus pole sõnaraamatuid (8. ja 9. klassist).

Küsimus sõnaraamatute olemasolust koolides andis peaaegu samasuguse tulemuse (99,7\%). Üks laps jättis sellele küsimusele vastamata.

Mis sõnaraamatuid kodus ja koolis leidub? Valikvastuste abil täpsustati, mis sõnaraamatud õpilastel kodus ja koolis on. Vastusteks olid pakutud järgmised variandid: ÕS, "Võõrsõnade leksikon"/"Võõrsõnastik”, inglise-eesti sõnaraamat (ükskõik milline), eesti-inglise sõnaraamat (ükskõik milline), veneeesti sõnaraamat (ükskõik milline), eesti-vene sõnaraamat (ükskõik milline), mõni muu. Muu puhul paluti märkida pealkiri/pealkirjad või ligilähedane pealkiri, kui meelde tuleb; võis märkida ka elektroonilisi sõnaraamatuid CD-ROM-il. Ühe vastusevariandina oli antud ka võimalus öelda, et vastaja kodus pole sõnaraamatuid.

Kui võrrelda ükskeelse ja kakskeelse sõnaraamatu olemasolu laste kodudes, siis ülekaalukalt esikohal on kakskeelne sõnaraamat. Tõenäoliselt kajastab selline olukord väikese rahva omapära, kus palju suheldakse välismaalastega nii tööalaselt kui ka perekondlikult, mistõttu ongi kakskeelseid sõnaraamatuid kodudes rohkem, sest vajadus nende järele on lihtsalt suurem. Ilmselt ei kerki inimestel eesti keele kohta nii palju küsimusi, et nt ÕS-i igapäevaselt niimoodi vajataks kui kakskeelset sõnaraamatut.

Muude sõnaraamatute all nimetati enamasti kakskeelseid sõnaraamatuid (prantsuse-eesti, saksa-eesti, hispaania-eesti, soome-eesti, inglise-vene sõnaraamat), aga ka inglise ükskeelset sõnaraamatut jm. Enamasti teavad lapsed oma kodus olevat kaks või enam sõnaraamatut (vaid üks 9. klassi laps märkis, et tal on ainult ÕS). Ligi kolmandikul kõikidest vastanutest (27,6\%) on kodus olemas 7 või enam sõnaraamatut (ehk kõik etteantud sõnaraamatud). Noorimas rühmas oli selliseid vastajaid 10,1\%, keskmises rühmas 6,6\% ja vanimas rühmas 40,2\%. Mõnevõrra üllatav on tõdeda, et keskastme laste kodudes on vähem sõnaraama-

Tabel 1. Kodus olevate sõnaraamatute pingerida vastanute seas

\begin{tabular}{|l|c|}
\hline Sõnaraamatu tüüp & Protsent \\
\hline Inglise-eesti sõnaraamat & $95,4 \%$ \\
\hline Eesti-inglise sõnaraamat & $90,8 \%$ \\
\hline Vene-eesti sõnaraamat & $78,6 \%$ \\
\hline Eesti-vene sõnaraamat & $72,6 \%$ \\
\hline Võõrsõnade leksikon / Võõrsõnastik & $72,1 \%$ \\
\hline ÕS & $61,0 \%$ \\
\hline Muu & $56,9 \%$ \\
\hline Pole sõnaraamatuid & $0,5 \%$ \\
\hline
\end{tabular}


tuid kui noorimatel lastel, võõrkeelte lisandudes võiks eeldada, et vastavate keelte sõnaraamatud endale muretsetakse.

Keskmiselt on lastel kodus kokku 5,3 sõnaraamatut, mis on minu meelest väga palju. R. Hartmanni poolt uuritud tudengitel on keskmiselt 5,9 sõnaraamatut. Andmed sõnaraamatute olemasolu kohta vastanute kodudes on toodud tabelis 1 .

Vastustest selgus, et kui lapsel on olemas inglise-eesti sõnaraamat, siis on tal ka eesti-inglise (selliseid oli 88,3\%). Samas ei saa olla päris kindel, et nad tegid neil sõnaraamatutel nii selget vahet, võidi mõelda ka neid kahte keelt, mitte konkreetseid suundi. Põhikooli algastmes ja gümnaasiumis leidus selliseid vastajaid kõige rohkem (vastavalt 92,4\% ja 91,7\%), kõige vähem esineb mainitud kaht sõnaraamatut korraga põhikooli keskastmes (83,5\%). Klassiti paistab, et kahe sõnaraamatu korraga esinemine on suurem nooremates klassides ja viimases klassis.

\subsection{Sõnaraamatute kasutamisest}

Selles küsimustiku osas küsiti, kus ja millal puutusid õpilased sõnaraamatuga esimest korda kokku, missuguseid sõnaraamatuid nad koolis kasutavad, kuidas nad tundmatu tekstiga ümber käivad ja mille jaoks nad sõnaraamatut kasutavad.

Kus puutub laps esimest korda sõnaraamatuga kokku? Sõnaraamatu kasutamist alustatakse üldjuhul kodus $(85,1 \%)$, koolis alustas kasutamist umbes üks laps kümnest (12,7\%). Üks laps väitis, et pole sõnaraamatuid kasutanud, kuid vastused mitmele järgmisele küsimusele näitavad, et ta neid siiski kasutab. Viis last tõenäoliselt ei mäleta, millal nad alustasid, kuna pakkusid vastuseks kodu ja kooli korraga. Üks gümnaasiumiõpilane aga vastas “ei mäleta”.

Tõenäoliselt tekib vajadus kasutada sõnaraamatut kodus koolitöid tehes, võimalik, et on lapsi, kes ise sõnaraamatust järele vaatavad, ja kindlasti soovitavad seda lapsevanemad. Lastele on tehtud ka mitmeid sõnamänge, mis põhinevad uute sõnade äraarvamisel, nii tekib vajadus sõnaraamatu järele kindlasti. Kuuldavasti on ka selliseid mänge, kus laste omavahelist sõnamängu alustatakse sõnaraamatust, kus üks ütleb, milliselt leheküljelt mitmendat sõna peab ta teise "mängimise" peale arvama hakkama.

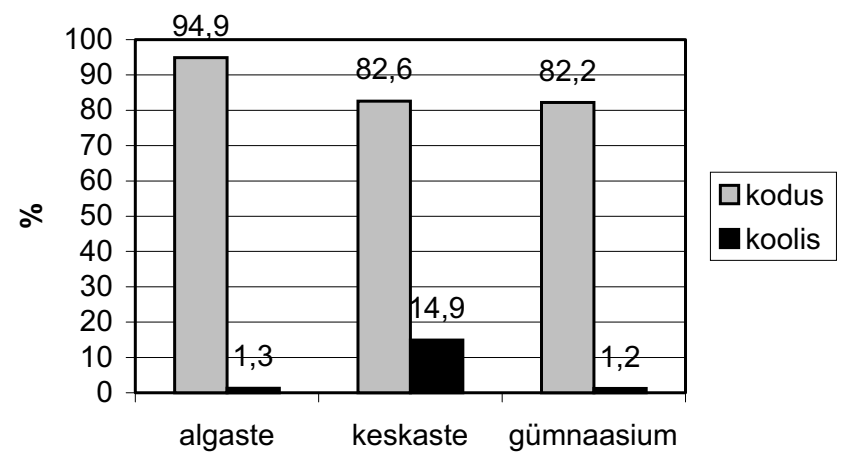

Joonis 2. Sõnaraamatu esmakordse kasutamise jagunemine kodu ja kooli vahel rühmade kaupa 
Mis vanuses kasutatakse sõnaraamatut esimest korda? Küsimus ise pärineb viimasest, kasutaja probleeme käsitlevast alajaotusest. Küsitud oli, millal alustasid õpilased sõnaraamatu kasutamist, kas algkoolis (1.-4. kl), põhikoolis (5.-9. kl), keskkoolis või gümnaasiumis (10.-12. kl), või nad ei mäleta. Rohkem kui pool küsitletud lastest (59,9\%) on teinud sellega algust juba algkoolis, suur hulk $(37,4 \%)$ ka põhikoolis ja vaid kaks last alustas gümnaasiumis. Üks laps ei mäleta, millal ta alustas. Kodu ja kooli kasutuse vahekorda rühmiti näitab joonis 2.

Jooniselt on näha, et keskastme hinnang erineb teistest oluliselt. Võimalik, et keskaste teab/mäletab sõnaraamatu kasutamise aega kõige täpsemalt (ja et koolis alustamine ongi tavaline), nooremad ei ole keskastmesse veel jõudnud ning võib-olla on neil häbi tunnistada, et nad pole sõnaraamatut veel kasutanud, samas gümnaasium enam ei mäleta täpselt, millal nad alustasid. Rääkides veel noorimatest: küsimus oli formuleeritud "millal alustasid sõnaraamatu kasutamist?”, minevikuvorm võis anda vastamisesuuna kätte, lapsed eeldasid, et nad peavad tingimata andma mingi aja (kuigi oli ka võimalik vastata: "Ma pole sõnaraamatut veel kasutanud.").

Kui võrrelda omavahel sõnaraamatu esmakordse kasutamise aega ja kohta, on tulemused järgmised. Neil, kes alustasid sõnaraamatute kasutamist kodus, langes see enamasti algkooli aega (64,3\%), neist aga, kes alustasid sõnaraamatute kasutamist koolis, alustas enamik hiljem, põhikooli ajal (59,6\%). Tabel 2 kajastab tulemusi täpsemalt.

Tabel 2. Sõnaraamatu esmakordse kasutamise aeg ja koht

\begin{tabular}{|l|c|c|}
\hline aeg/koht & kodus & koolis \\
\hline algkoolis & $64,3 \%$ & $36,5 \%$ \\
\hline põhikoolis & $34,8 \%$ & $59,6 \%$ \\
\hline gümnaasiumis & $0,3 \%$ & $3,8 \%$ \\
\hline
\end{tabular}

Lapsed, kes on alustanud sõnaraamatu kasutamist kodus ja teinud seda juba algkooliastmes, omavad kodus ka rohkem sõnaraamatuid (31,2\% lastest on kodus 7 või enam sõnaraamatut) kui need, kes alustasid sõnaraamatu kasutamist koolis ja põhikooliastmes $(21,1 \%)$. Ühtpidi võttes on loomulik, et kui laps on sõnaraamatutega pikemat aega "tuttav", siis oskab ta neid endale ehk rohkem tahta. Teistpidi võttes - kui kodus on palju sõnaraamatuid, siis hakkavad lapsed neid ka varem kasutama. Tõenäosus, et lapsed lahendavad sõnavaraprobleeme pigem kodusõnaraamatutega kui koolisõnaraamatutega, on suurem just varases eas.

Sõnaraamatu kasutamine koolis. Siin pidid vastajad ära märkima sõnaraamatud, mida nad koolis kasutavad. Valikute hulka kuulusid: ÕS, "Võõrsõnade leksikon" / "Võõrsõnastik", inglise-eesti sõnaraamat (ükskõik milline), eesti-inglise sõnaraamat (ükskõik milline), vene-eesti sõnaraamat (ükskõik milline), eestivene sõnaraamat (ükskõik milline), õpikute taga olevad sõnastikud, mõni muu (paluti märkida pealkiri/pealkirjad või ligilähedane pealkiri, kui meelde tuleb). Võis ka öelda, et vastaja koolis sõnaraamatuid ei kasuta. 
Kõige rohkem kasutavad lapsed õpikute taga olevaid sõnastikke. Ilmselt on selle taga õige mitu asjaolu. Võimalik, et koolis ei ole igas klassis sõnaraamatuid, ja kui ka on, siis pole neid võõrkeele tunnis väga vaja, piisab õpikutes leiduvatest sõnastikest. Samas, kui klassis on sõnaraamatud, siis põhjus, miks neid ei kasutata, seisneb ehk ka õpilase laiskuses, õpikute taga olevaid sõnastikke on igal juhul mugavam kasutada. Võib olla, et ka õpetajad ei suuna lapsi mujale otsima ja piirduvad õpikutega. Koolis kasutatakse ükskeelset ÕS-i rohkem kui kakskeelset inglise-eesti sõnaraamatut, st eesti keele tunnis kasutatakse sõnaraamatut rohkem kui inglise keele tunnis. Eeltoodud andmetel kodusõnaraamatute kohta domineerib kodudes kakskeelne inglise-eesti sõnaraamat. See, et koolides kasutatakse ükskeelset ÕS-i rohkem kui kakskeelset inglise-eesti sõnaraamatut, võib kõneleda kahest asjaolust. Ilmselt näiteks inglise keele tunnis lahendataksegi sõnavaraprobleemid õpikute taga olevate sõnastikega. Eesti keele õpikute taga aga minu teada selliseid õppetükkide sõnastikke ei ole, on vaid mõnede võõramate sõnade loendid seletustega - emakeeletunnis osutub ÕS hädavajalikuks. ÕS-i abil lahendatakse ilmselt ka eesti keele ülesandeid, harjutatakse õigekirja jms. Sõnaraamatute tarvitamist koolis kujutab tabel 3.

Tabel 3. Koolis kasutatavate sõnaraamatute pingerida

\begin{tabular}{|l|c|}
\hline Sõnaraamatu tüüp & Protsent \\
\hline Sõnastikud õpikute taga & $66,4 \%$ \\
\hline ÕS & $55,3 \%$ \\
\hline Inglise-eesti sõnaraamat & $46,3 \%$ \\
\hline Vene-eesti sõnaraamat & $41,7 \%$ \\
\hline Eesti-vene sõnaraamat & $39,8 \%$ \\
\hline Eesti-inglise sõnaraamat & $35,2 \%$ \\
\hline Võõrsõnade leksikon / Võõrsõnastik & $29,0 \%$ \\
\hline Muud & $9,5 \%$ \\
\hline
\end{tabular}

Vanuserühmade kaupa ilmnevad teatud erinevused: kõige usinamalt kasutavad õpikute taga olevaid sõnaraamatuid noorimad lapsed, samas kui nende hulgas on kõige vähem ÕS-i vajajaid. On loomulik, et ÕS-i kasutus kasvab laste vanemaks saades, samuti inglise-eesti sõnaraamatu kasutus. Samas on pisut üllatav, et õpikute taga olevate sõnastike kasutus tõuseb keskastmes, kus see loogiliselt peaks langema ja inglise-eesti sõnaraamatu kasutus oluliselt tõusma.

Kui kõrvutada andmeid kodu ja kooli kohta, ilmneb, et üle poole $(58,6 \%)$ ÕS-i omanikest kasutab seda sõnaraamatut ka koolis (võrdluseks: võorsõnastiku omanikest kasutab seda ka koolis rohkem kui neljandik, 27,4\%). Tõenäoliselt katab ÕS suure osa koolis käsitletavatest võõrsõnadest ja võõrsõnastikku pole tunnis lihtsalt vaja. Samas antakse õpilastele kodus tegemiseks palju iseseisvat tööd, läbitöötatavat materjali on rohkem kui tunnis käsitletakse: tõenäoliselt läheb kodus võõrsõnastikku jälle vaja, ilmselt ÕS üksi ei ammenda neid vajadusi (ja 
Tabel 4. Koolis kasutatavad sõnaraamatud vanuserühmade kaupa

\begin{tabular}{|l|c|c|c|}
\hline & Õpikutes & ÕS & Ingl-ee \\
\hline algaste & $58,2 \%$ & $11,4 \%$ & $38,0 \%$ \\
\hline keskaste & $73,6 \%$ & $66,1 \%$ & $41,3 \%$ \\
\hline gümnaasiumiaste & $65,1 \%$ & $68,0 \%$ & $53,8 \%$ \\
\hline
\end{tabular}

ÕS-e pole kodudes nii palju). Seda tõendavad ka eeltoodud andmed, mille järgi on kodudes võõrsõnastikke rohkem kui ÕS-e. Siin võib oma osa olla ka kirjastuse edukal reklaamikampaanial.

Elektrooniline sõnaraamat. Elektrooniliste sõnaraamatute all mõeldi nii sõnaraamatuid CD-ROM-il kui ka Interneti-sõnaraamatuid. 2/3 vastanutest on elektroonilisi sõnaraamatuid kasutanud ja kolmandik ei ole. Juba algastmes on elektroonilisi sõnaraamatuid kasutanud üle poole vastajaist (53,2\%), keskastmes ligi kolmveerand vastanutest $(73,2 \%)$, gümnaasiumiastmes oli kasutajaid kõige enam (82,2\%).

Küsimuse peale, mida nad on kasutanud, leidus vastuseid seinast seina. Kõige rohkem kasutatakse inglise-eesti ja eesti-inglise sõnaraamatuid, kusjuures ei täpsustatud, kas Internetis leiduvaid või sõnaraamatuid CD-del. Suhteliselt palju kasutatakse erinevaid inglise-inglise sõnaraamatuid. Oli ka neid lapsi, kes märkisid, et kasutavad sõnaraamatutena erinevaid otsimootoreid (neti.ee, google.com), samas mõned ei osanud üldse mainida, mida nad kasutavad.

Tundmatu tekst ja sõnaraamat. Vastajatel paluti valida, kuidas nad käituvad, kui loevad tundmatut eestikeelset teksti, kus on palju sõnu, mille tähendust nad ei tea. Pakutud oli järgmisi valikuvõimalusi: ei tee midagi, püüan arvata sõna tähendust lause mõtte järgi, küsin vanemate/sõprade/targemate käest, uurin sõnaraamatust, teen hoopis midagi muud (paluti kirjeldada, mida).

Kõige rohkem kasutavad lapsed kolme võimalust korraga: pea iga viies vastaja (22\%) püüab nii arvata konteksti järgi, küsida kellegi käest ja uurida ka sõnaraamatust. Kolme võimalust korraga kasutavad kõige enam gümnaasiumiõpilased ja kõige vähem algastme lapsed. Mõni laps moodustas koguni pingerea esmalt püüan ise arvata, siis küsin kellegi käest ja kui see ei aita, siis vaatan sõnaraamatust. Selline järjestus näitab, et sõnaraamatust järelevaatamine on tülikam, inimese loomupärase laiskuse tõttu võib isegi lugeda ootuspäraseks kasutada esmalt teisi, mugavamaid võimalusi. Võiks ka arutleda selle üle, kuivõrd lapsed sõnaraamatutes leiduvat infot usaldavad, selline pingeritta panek võib osutada sellelegi, et lapsed usaldavad iseennast ja teisi rohkem kui sõnaraamatut. Kindlasti järeldub siit, et sõnaraamat on keeruline ja ebamugav abivahend. Kuna antud küsimus ei näita siiski selgelt sõnaraamatu positsiooni lapse silmis, siis võib neid järeldusi vaid spekulatsioonideks pidada, kuid mõtlemisainet see annab.

Teine viiendik lapsi $(20,4 \%)$ küsib kellegi käest ja vaatab ka sõnaraamatust. 15,2\% vastanutest arvab sõna tähendust lause mõttest ja küsib kellegi käest. Peaaegu võrdne hulk lapsi kas ainult küsib $(12,2 \%)$ või ainult vaatab sõnaraamatust $(11,7 \%)$. Küsijad on ülekaalus noorimate seas (rohkem kui neljandik alg- 
astmest), sõnaraamatust vaatajad vanemate seas, jagunedes peaaegu võrdselt keskastme ja gümnaasiumiastme vahel.

Vähem kui kümnendik vastanutest (9\%) ei tee muud kui püüab sõna tähendust ära arvata. Kõige rohkem arvavad keskastme lapsed. 5,7\% vastanuid arvab sõna tähendust kontekstist ja vaatab sõnaraamatust.

Vaid 1,9\% vastanutest ei võta mitte midagi ette, kui kohtavad tekstis tundmatuid sõnu. 1,3\% kasutab teisi võimalusi, näiteks otsivad Internetist või katsuvad tuletada midagi mõne teise keele kaudu.

Lapsed ei kasuta ainult üht võimalust midagi teada saada, vaid paari või lausa kolme, ning üle poolte lastest $(60,4 \%)$ kasutavad ühe võimalusena mitmest ka sõnaraamatut.

Mille jaoks sõnaraamatut kasutatakse. See küsimus jaguneb kahte suuremasse rühma: eesti keelega seotud tegevused ja võõrkeelega seotud tegevused. Need puudutasid mõlema keele (keelte) võõraid tähendusi, lisainfot tähenduse kohta, hääldust, muutmist, suhtlemist ja muud.

Enamik lapsi kasutab sõnaraamatut siis, kui nad ei tea võõrkeelse sõna tähendust. Veidi vähem kasutavad nad sõnaraamatut siis, kui peavad tõlkima võõrkeelset kooliteksti eesti keelde või vastupidi ning kui nad ei saa aru eestikeelse sõna tähendusest. Kokkuvõttes võib öelda, et suurima probleemide rühma, mida sõnaraamatuga lahendatakse, moodustab sõna või lause tähendus.

Märgatavalt vähem kasutatakse sõnaraamatut välismaa sõbrale kirja kirjutamiseks või temaga arvuti abil suhtlemiseks ning siis, kui ei osata moodustada võõrkeelse sõna käänet või pööret.

Hääldusprobleemide lahendamiseks kasutatakse sõnaraamatut peaaegu sama vähe kui eestikeelse sõna tähendusele lisainfo hankimiseks.

Joonis 3 kajastab, kuidas jaguneb kirjeldatud tegevuste lahendamine sõnaraamatuga rühmade vahel.

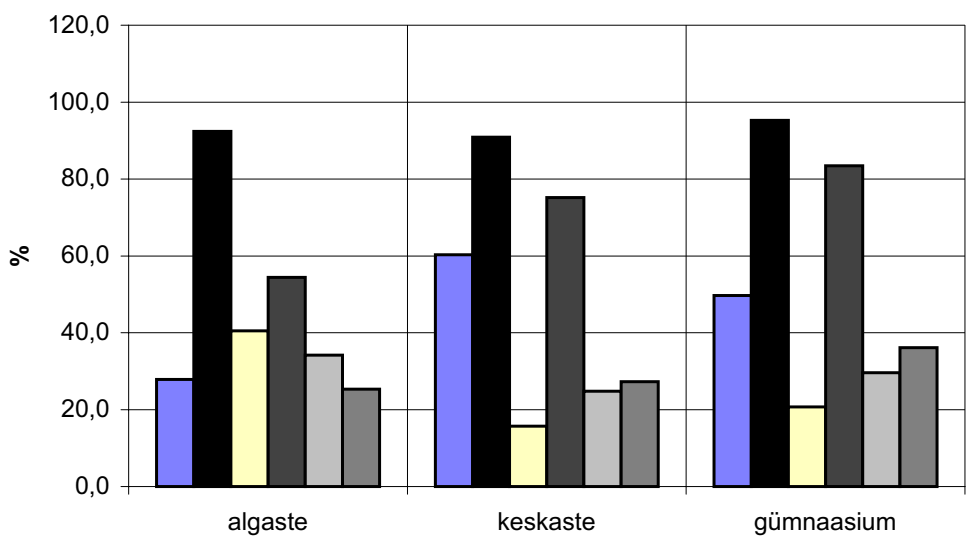

$\square$ Ee täh $\square$ Võõr täh $\square$ Võõr hääld $\square$ tõlkimine $\square$ Võõr muut $\square$ kirjutamine

Joonis 3. Mida sõnaraamatust otsitakse. Lühendid: Ee täh = eestikeelse sõna tähendus; Võõr täh = võõrkeelse sõna tähendus; Võõr hääld = võõrkeelse sõna hääldus; Võõr muut = võõrkeelse sõna muutmine 
Rühmade analüüsist selgub, et kõigil rühmadel ühtviisi läheb sõnaraamatut kõige rohkem vaja võõrkeelse sõna tähenduse leidmiseks ja teksti tõlkimiseks. Vanemasse astmesse liikudes kasvab tõlkimismaht, seda tõendab ka joonisel 3 kajastuv järjest kasvav vajadus tõlkimisel sõnaraamatut kasutada.

Noorimal rühmal paigutub kolmandale kohale võõrkeelse sõna hääldus, samas kui kahel järgmisel rühmal on rohkem probleeme eestikeelse sõna tähendusega. On mõnevõrra loomulik, et väiksematele on vaja sõnaraamatut võõrkeelse sõna häälduse teadasaamiseks, kuna nad on võõrkeele õppimisega alles alustanud ning vajavad ses osas vanematest rohkem abi. See, miks keskmisele rühmale eestikeelse sõna tähendus suuri raskusi valmistab, on ehk seletatav uute ainete, eriti reaalainete lisandumisega õppekavva, mistõttu nad vajavad tähenduse lahtiseletamiseks sõnaraamatu abi. Ühtviisi vajalikuks peavad kõik rühmad kasutada sõnaraamatut välismaal elavale sõbrale kirja kirjutamisel või temaga arvuti abil suhtlemiseks.

\subsection{Sõnaraamatu kasutaja probleemidest}

Selles osas pidi õpilane vastama küsimustele, mis puudutasid info ülesleidmist sõnaraamatust, pakkuma lahendusi mitteleidmise korral ja esitama sõnaraamatuga seonduvaid probleeme. Viimased küsimused käsitlesid kasutamisoskust, seal pidid vastajad hindama, kuidas nad enda meelest sõnaraamatut kasutada oskavad, kas neile on seda õpetatud ja kas peaks õpetatama.

Kas laps leiab, mida otsib. Selgus, et enamasti lapsed leiavad sõnaraamatust üles selle, mida otsivad. Niimoodi arvas $60,7 \%$ vastanutest. Päris veendunud "jah, leian" vastajaid oli poole vähem (33,3\%). Leidus ka neid, kes lugesid kaks erinevat vastusevarianti "jah" ja "enamasti” üheks vastuseks "jah, enamasti” (neid oli 8 last). Mõni arvas, et vahel leiab (5 last). Neid lapsi polnudki, kes üldse ei leia. Leidus küll neid, kes arvasid, et enamasti ikka leiavad, aga kui ei leia, siis sellepärast, et sõnaraamat on vana. Üldiselt ei palutud siin lastel põhjendada, miks nad ei leia. Võib tõdeda, et sõnaraamatud ei vea lapsi alt, kuigi vastustest ei selgu, kas see, mis lapsed sealt leiavad, neid ka rahuldab.

Kui ei leia, mida siis tehakse. Siin oli lastel võimalik valida, kas nad viskavad raamatu käest ja asuvad teise tegevuse juurde, otsivad Internetist (paluti täpsustada, kas Interneti-sõnaraamatust või mujalt Internetist), küsivad vanemate/ sõbra/targema käest või otsivad mõnest teisest sõnaraamatust.

Taas kord kasutavad lapsed mitut võimalust korraga. Kõige rohkem küsitakse kellegi käest ja otsitakse mõnest teisest sõnaraamatust (20,1\%). Sellist kombinatsiooni kasutasid enim noorimad vastajad. Pisut vähem oli neid vastajaid, kes küsisid kelleltki (19,5\%), seda võimalust kasutasid kõige rohkem keskastme lapsed. 14,1\% lastest kasutas võimalust Internetist vaadata, kellegi käest küsida ja teisest sõnaraamatust otsida. Sellest võimalusest haarasid kõige agaramalt vanimad vastajad, mis on ka ootuspärane, kuna nad teavad erinevaid infootsimisvõimalusi tõenäoliselt kõige paremini.

Lapsi, kes asuvad mõne teise sõnaraamatu kallale ega kasuta lisaks muid võimalusi, oli kokku 12,7\%. Selliseid leidus kõige enam noorimate seas. Pisut 
vähem oli neid, kes ainsa võimalusena kasutavad Internetti $(11,4 \%)$, vanima vanuserühma lapsed on selles osas kõige usinamad.

Kasutati veel võimalust uurida Internetist ja küsida kellegi käest (7,6\%). Väike osa lapsi viskab raamatu käest (neid oli kõige rohkem keskmise ja vanima vanuserühma seas) ja hakkab midagi muud tegema (6\%); kasutatakse ka kombinatsiooni Interneti-otsing ja sõnaraamat (4,3\%).

Selle küsimuse tulemused langevad kokku tulemustega, mis saadi tundmatu teksti lahendamise juures. Teiste käest küsimine on nähtavasti mugavaim viis midagi teada saada.

Raskused sõnaraamatu kasutamisel. Siin paluti lastel vastata, kas neile valmistab kõige rohkem raskusi see, et ei leia sõna, sõna tähendust, ei saa aru, mida mõeldakse (nt ei saa paljudest lühenditest ja märkidest aru jms), kuidas sõna kasutada, pöörata/käänata või miski muu. Olulisemad probleemid on toodud tabelis 5 .

Tabel 5. Probleemid sõnaraamatu kasutamisel

\begin{tabular}{|l|c|}
\hline Ei leia sõna & $23,8 \%$ \\
\hline Ei saa mõttest aru & $21,1 \%$ \\
\hline Muu & $8,1 \%$ \\
\hline Ei saa muutmisest aru & $7,9 \%$ \\
\hline Ei leia tähendust & $6,2 \%$ \\
\hline Ei saa kasutusest aru & $4,6 \%$ \\
\hline
\end{tabular}

Muu all mainiti mitmeid probleeme: otsitakse kogemata vale sõna, otsitakse sõna häälduse järgi, aga mitte kirjapildi järgi ja siis ei leita seda, sõna puudub sõnaraamatust. Muu all märgiti õige mitmel juhul, et sõnaraamatu kasutamine ei valmista mingeid raskusi.

Kõige rohkem probleeme valmistab sõna mitteleidmine noorimatele, mida võib iseenesest loomulikuks pidada, sest sõnaraamatu kasutamise harjumus alles tekib. Samas ei saa siinkohal olla kindel, kas lapsed ei leia sõna sellepärast, et nad ei oska otsida, või sellepärast, et seda sõna sõnaraamatus polegi. On mõtlemapanev, et nii palju lapsi ei saa aru, mida sõnaraamatus öelda tahetakse. Kindlasti annab see mõtteainet nii sõnaraamatu metateksti keerulisuse kui ka laste kasutusoskuste üle.

Kasutamisoskuse hindamine. Üle poolte lastest pidas oma kasutamisoskust väga heaks või heaks: $55 \%$ lastest teab tavaliselt, kust ja kuidas otsida. Kõige kõrgema enesehinnanguga olid gümnaasiumiõpilased (86,8\%), kõige vähem olid oma oskustes kindlad noorimad, algastme lapsed.

Veidi alla poole lastest (41,5\%) peab oma kasutamisoskust keskmiseks: kord leiavad, kord ei leia, ja miks see nii on, ei tea. Huvitaval kombel pidasid oma kasutusoskust keskmiseks noorimad. Siin ei pea paika üldine tendents vanemaks saades end kriitilisemalt hinnata. 
Päris halvaks pidas oma kasutamisoskust vaid $1 \%$ vastanutest. Need lapsed ei leia kunagi midagi, alati läheb kaua aega, nad arvavad juba ette, et nad nagunii midagi ei leia. Nii hindasid ennast 2 keskastme ja 3 gümnaasiumi õpilast.

Kas sõnaraamatute kasutamist on lastele õpetatud. Üks kolmandik vastanutest arvas, et on õpetatud, teine kolmandik aga (29,8\%) arvas, et ei ole, veerand $(25,5 \%)$ leidis, et vist on ja vähem kui kümnendik ei mäletanud, kas on õpetatud. Küsimus ei täpsusta, kas neile on seda õpetatud koolis või kodus, kes seda neile õpetas ja millal täpselt seda on tehtud.

Kas kasutamist peaks õpetama. Siin selgus, et $2 / 3$ vastanutest peab sõnaraamatute kasutamise õpetamist vajalikuks. Seejuures üle poole neist, kes peavad seda vajalikuks, on need, kellele on kasutamist ka õpetatud. Kolmandik vastanutest ei pea sõnaraamatute kasutamise õpetust vajalikuks. Suur osa nii arvanutest on need, kellele pole (või vist on või nad ei mäleta) sõnaraamatute kasutamist õpetatud. Iseenesest on loomulik, et need, kes on õpetamisest kasu saanud, seda ka vajalikuks peavad ja vastupidi.

\section{Kokkuvõte}

Eestis esmakordselt läbiviidud küsitluse tulemuste analüüs näitas, et Eesti koolilastel on olemas märkimisväärne sõnaraamatu kasutamise kogemus juba õige varases eas. Laste vastuste järgi otsustades on eestlaste kodudes muljetavaldav hulk sõnaraamatuid; Eesti kooliõpilased teavad üldiselt, kust ja kuidas infot otsida, kasutavad info hankimiseks ka muid võimalusi peale sõnaraamatu ning on üldse oma püüdlustes suhteliselt järjekindlad ja positiivselt meelestatud.

Suurimaks probleemiks sõnaraamatute kasutamise juures peab Eesti laps seda, et ta ei leia sõnaraamatust sõna üles ega saa sageli aru, mida sõnaraamatus talle öelda tahetakse. Siin on mõtlemisainet mõlemas suunas: nii leksikograafidele (lihvida sõnaraamatute metakeelt) kui ka kasutajaile endile (arendada kasutajaoskusi).

Mis puutub õpetamisse, siis Eesti koolilapsele on tema väitel sõnaraamatute kasutamist pisut õpetatud ja vaatamata sellele, et ta ise on oma kasutamisoskustega enam-vähem rahul, arvab ta, et selline õpetus võiks tulla kasuks.

\section{Kirjandus}

Atkins, Sue B. T.; Varantola, Krista 1997. Monitoring Dictionary Use. - International Journal of Lexicography 1, 1-39.

Atkins, Sue B. T.; Varantola, Krista 1998. Language Learners Using Dictionaries: The Final Report on tje EURALEX / AILA Research Project on Dictionary Use. Lexicographica Series Maior 88. Tübingen: M. Niemeyer, 21-81.

Barnhart, Clarence 1962. Problems in editing commercial monolingual dictionaries. Problems in Lexicography. Bloomington: Indiana U.P., 161-181.

Béjoint, Henri 1981. The Foreign Student's Use of Monolingual English Dictionaries: A Study of Language Needs and Reference Skills. - Applied Linguistics 2, 3, 207-222.

Béjoint, Henri 2000. Modern Lexicography. New York: Oxford Univerity Press. 
Bogaards, Paul 1999. Research on Dictionary Use: An Overview. - Recommendations, National Reports and Thematic Reports from the TNP Sub-Project 9: Dictionaries. http://www.fu-berlin.de/elc/tnp1/SP9dossier.pdf (05.03.2005), 32-35.

Bogaards, Paul 2003. Uses and Users of dictionaries. - A Practical Guide to Lexicography. Amsterdam: John Benjamins Publishing Company, 26-33.

Hartmann, Reinhard R. K. 1982. Daszweisprachige Wörterbuch im Fremdsprachenerwerb. - Germanistische Linguistik 3-6/80, 73-86.

Hartmann, Reinhard R. K. (ed.) 1999. Case Study: The Exeter University Survey of Dictionary Use. - Dictionaries in Language Learning. Recommendations, National Reports and Thematic Reports from the TNP Sub-Project 9: Dictionaries. www.fuberlin.de/elc/TNPproducts/SP9dossier.doc (05.03.2005), 36-52.

Lew, Robert 2002. Questionnaires in Dictionary Use Research: A Reexamination. - Euralex 2002 Proceedings, 267-271.

McCreary, Don R.; Dolezal, Fredric T. 1999. A Study of Dictionary Use by ESL Students in an American University. - International Journal of Lexicography 2, 107-145.

Tono, Yukio 1998. Interacting with the users: research findings in EFL dictionary user studies. - Lexicography in Asia 1998, 97-118.

Wiegand, Herbert, 1998. Wörterbuchforschung. Untersuchungen zur Wörterbuchbenutzung, zur Theorie, Geschichte, Kritik und Automatisierung der Lexicographie. Berlin: W. de Gruyter.

\section{Kaudviited}

Hatherall, Glynn 1984. Studying Dictionary Use: Some findings and proposals. - LEXeter '83 Proceedings, 183-189.

Scholfield, Philipp 1999. Dictionary Use in Reception. - International Journal of Lexicography $12,13-34$. 


\section{THE ESTONIAN SCHOOLCHILD AS A DICTIONARY USER Ruth Mägi}

The research project about the dictionary user's reference needs and skills was carried out among Estonian schoolchildren during 2004-2005. 369 schoolchildren from the grades 4-12 were questioned, and the results of this questionnaire are introduced in this article. Estonian schoolchild as the dictionary user owns a remarkable set of dictionaries and has quite good using experience from the early age. $\mathrm{He} /$ she knows where and how to look up words, he/she is also familiar with the different additional sources beside the dictionary. Although he/she doesn't succeed all the time, he/she is positively-minded and persistent in his/her pursuits. The biggest problem in dictionary use is the fact he/she doesn't find the word in the dictionary and sometimes he/she doesn't understand what the dictionary tells him/her. In the further research it might be useful to work on the (sentence) formulation of the metalanguage or on improving the dictionary users' skills. Estonian schoolchild has been introduced how to use dictionaries and he/ she is satisfied with his/her user's skills, however, he/she is quite sure that more teaching might be useful indeed.

Keywords: lexicography, pedagogical lexicography, dictionary use, metalexicography, language learner, Estonian language

Ruth Mägi (1974) on lõpetanud Tartu Ülikooli eesti filoloogia erialal. Töötab TEA Kirjastuses sõnaraamatute osakonna peatoimetajana ning õpib Tallinna Ülikoolis eesti filoloogia osakonnas lingvistika eriala magistriõppes. Uurimisvaldkonnad: leksikograafia üldiselt, pedagoogiline leksikograafia, sõnaraamatute kasutaja ja kasutamine.

ruth.magi@tea.ee 